\title{
PEMODELAN PERSAMAAN MODUL PHOTOVOLTAIC YANG MEMILIKI DIODA BYPASS PADA SAAT GANGGUAN SHADING
}

\author{
Andrew Jussac Jusran ${ }^{1}$, \\ Program Studi Teknik Elektro Universitas Trisakti \\ Email: andrew.yusran@gmail.com \\ Chairul G. Irianto ${ }^{1}$, \\ Program Studi Teknik Elektro Universitas Trisakti \\ Email: chairul_irianto@trisakti.ac.id \\ Henry Chandra ${ }^{1}$ \\ Program Studi Teknik Elektro Universitas Trisakti \\ Email: henrcand@gmail.com
}

\begin{abstract}
S : Photovoltaic (PV) modules are devices that convert sunlight to electricity. The usages of PV modules become more popular from time to time. In a certain condition, $P V$ modules can have multiple problems. One of many problems found in usages of PV modules is shading. Shading is a condition where sunlight is blocked by objects that makes shadow around the surface of $P V$ modules which lead to a decreasing of productivity and efficiency in power generation. Shading issue can occurs to a single cell or group of cells in PV module which not only can cause a drastic decreasing in power generation but also can cause structure failure and fire. Equation modeling is needed to represent power, current, and voltage characteristic of $P V$ module when shading occurs. Method that used in this research is a synthesis of several method which is detailed equation modeling of PV module and varying shading amount of a PV module using Simulink MATLAB program. The results shows that current and voltage characteristic and power and voltage characteristic are representing $P V$ module behaviour in shading condition which can be analysed and lead to further research and development of PV devices and systems.
\end{abstract}

KEYWORD: Photovoltaic, Shading, Bypass Diode, Current and Voltage Characteristic, Power and Voltage Characteristic.

\begin{abstract}
ABSTRAK : Modul Photovoltaic (PV) adalah perangkat yang mengubah sinar matahari menjadi energi listrik. Penggunaan modul PV menjadi semakin populer dari waktu ke waktu. Pada kondisis tertentu, modul PV dapat mengalami gangguan. Salah satu gangguan dalam penggunaan modul PV adalah shading. Shading adalah kondisi di mana sinar matahari terhalangi oleh suatu objek, di mana objek tersebut menghasilkan bayangan pada permukaan modul PV yang mengakibatkan berkurangnya produktifitas dan efisiensi dari pembangkitan listrik. Gangguan shading dapat terjadi pada satu sel PV atau beberapa sel PV yang tidak hanya mengakibatkan berkurangnya pembangkitan listrik secara drastis tetapi juga kerusakan struktur dan kebakaran. Pemodelan persamaan diperlukan untuk merepresentasi karakteristik daya, arus dan tegangan pada saat terjadinya gangguan shading. Metode yang digunakan pada penelitian tersebut adalah sintesa dari beberapa metode yaitu pemodelan detail persamaan modul PV dan memvariasikan besaran gangguan shading pada modul PV menggunakan program Simulink MATLAB. Hasil dari penilitan memperlihatkan karakteristik arus dan tegangan dan karakteristik daya dan tegangan merepresentasikan modul PV pada saat mengalami shading di mana hasil tersebut dapat dianalisis dan digunakan untuk penelitian yang lebih lanjut dan pengembangan dari perangkat PV dan sistem PV.
\end{abstract}

KATA KUNCI: Photovoltaic, Shading, Dioda Bypass, Karakteristik Arus dan Tegangan, Karakteristik Daya dan Tegangan.

\section{PENDAHULUAN}

Sumber energi yang digunakan untuk membangkitkan listrik dibagi menjadi tiga kategori yaitu bahan bakar fosil, nuklir dan sumber energi terbarukan di mana sumber energi terbarukan merupakan sumber energi yang dapat menghasilkan energi yang bersih dan dapat bertahan dalam jangka waktu yang panjang [1]. Sumber energi terbarukan antara lain, tenaga surya, tenaga angin, laut, tenaga air, geothermal, hidrogen, dan biomassa [2]. Pemanfaatan tenaga surya sebagai pembangkit listrik dapat secara langsung dilakukan menggunakan perangkat Photovoltaic (PV) [3]. Perangkat PV yang adalah modul PV dapat mengalami beberapa gangguan. Salah satu gangguan pada penggunaan modul PV adalah shading. Shading merupakan fenomena di mana terdapat objek di sekitar atau di atas modul PV yang menghalangi sinar matahari sehingga mengakibatkan penurunan intensitas radiasi matahari pada modul PV [4]. Gangguan shading dapat disebabkan oleh objek seperti daun pohon yang gugur atau pohon yang lebih tinggi dari atap di mana modul PV terpasang [5]. Hal tersebut dapat menurukan produktifitas pembangkitan listrik, efisiensi, kehandalan dan keamanan dari sistem tersebut [6].

Pemodelan persamaan modul PV yang mengalami gangguan shading diperlukan untuk menganalisis akibat yang dihasilkan dari gangguan shading. Beberapa peneliti sudah melakukan pendalaman pemodelan persamaan dengan menggunakan berbagai metode yang berbeda. Pada penelitian tersebut, metode yang digunakan adalah mensintesa beberapa metode yaitu memodelkan

1 Universitas Trisakti 
persamaan modul PV yang memiliki dioda bypass dan modul PV yang tidak memiliki dioda bypass pada saat mengalami gangguan shading secara detail dan mengubah - ubah besaran gangguan shading untuk mendapatkan karakteristik arus dan tegangan dan karakteristik daya dan tegangan menggunakan program Simulink MATLAB.

\section{Jenis Photovoltaic}

\section{DASAR TEORI}

Istilah Photovoltaic (PV) pertama kali ditemukan oleh fisikawan perancis bernama Alexandre Edmon Becquerel pada awal tahun 1839 di mana sel PV terbuat dari bahan semikonduktor [7]. Jenis material yang digunakan beberapa di antaranya adalah monocrystalline dan polycrystalline [8]. Perangkat PV dimulai dari satu sel yang dirangkai menjadi satu panel yang disebut sebagai modul PV. Modul PV yang dikoneksikan secara seri atau atau paralel disebut dengan array. Pada sistem PV terdapat perangkat listrik lainnya, antara lain Maximum Power Point Tracker Solar Charge Controller (MPPTSCC), Baterai dan Inverter [9].

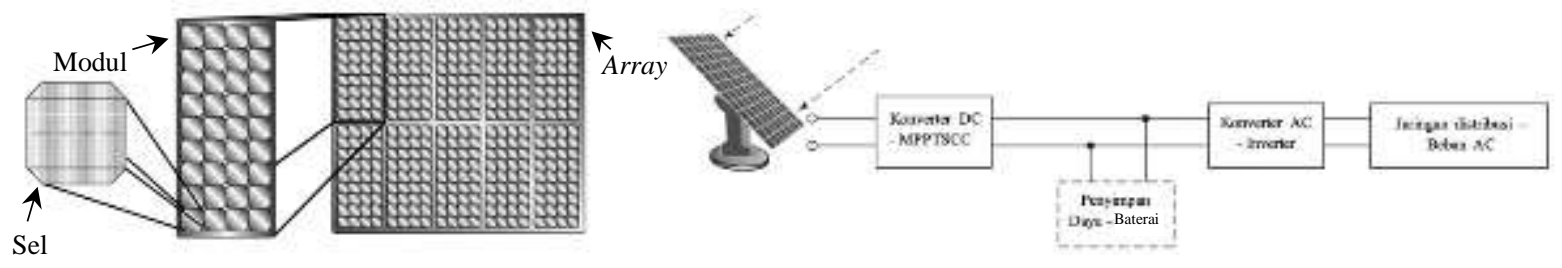

Gambar 1. Sel, Modul, Array dan Sistem PV.

\section{Persamaan Modul Photovoltaic}

Persamaan modul PV dimulai dari persamaan sel PV yang memiliki rangkaian ekivalen seperti Gambar 2 sebagai berikut.

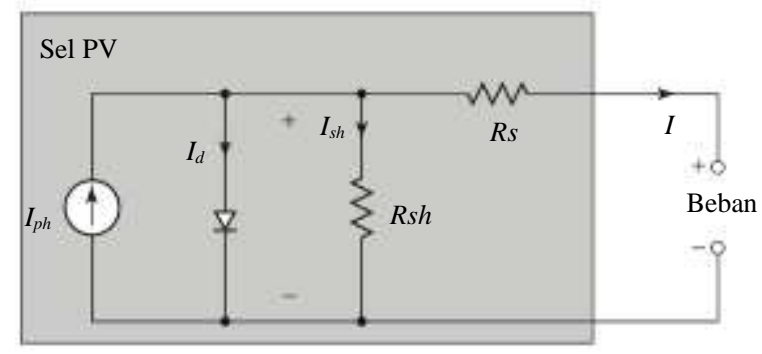

- Gambar 2. Rangkaian Ekivalen Sel PV dengan Hambatan Seri dan Paralel.

Gambar 2 menggambarkan arus yang dihasilkan oleh intensitas radiasi matahari atau irradiance adalah arus photo $\left(I_{p h}\right)$ dan arus dioda $\left(I_{d}\right)$ adalah arus saturasi dari material sel PV dan arus hambatan paralel $\left(I_{s h}\right)$ adalah arus yang dihasilkan dari rugi - rugi sel PV [10]. Sel PV yang dikoneksikan secara seri menjadi modul PV memiliki persamaan yang dituliskan ke dalam Persamaan 1 sebagai berikut [11].

$$
I=I_{p h}-I_{0}\left[\exp \left(\frac{V+I \cdot R s}{\mathrm{~A} \cdot N_{S} \cdot V_{T}}\right)-1\right]-\frac{V+I \cdot R s}{R_{S h}}
$$

Keterangan: $I=$ Arus Modul PV (A); $I_{p h}=$ Arus Photo (A); $I_{0}=$ Arus Dioda (A); $V=$ Tegangan Modul PV (V); $A=$ Faktor Ideal; $N_{\mathrm{S}}=$ Jumlah Sel; $k=$ Konstanta Blotzmann $\left(1.381 \times 10^{-23} \mathrm{~J} / \mathrm{K}\right)$; $R_{s}=$ Hambatan Seri $(\mathrm{Ohm}) ; R_{s h}=$ Hambatan Paralel $(\mathrm{Ohm})$.

\section{Gangguan Shading}

Gangguan shading disebabkan oleh bermacam - macam objek yang menghalangi sinar matahari. Objek yang mengakibatkan gangguan shading pun memiliki karakteristik yang berbeda - beda ada yang menghalangi sinar matahari secara sempurna, namun ada juga yang tetap melewatkan sebagian dari sinar matahari ke permukaan modul PV. Percobaan dan pengambilan data secara langsung mengenai 
gangguan shading sudah banyak dilakukan oleh peneliti - peneliti sebelumnya. Modul PV yang mengalami gangguan shading mempunyai risiko yang sangat tinggi untuk kehilangan kapasitas pembangkitan listrik dan juga risiko terjadinya kerusakan struktur. Satu sel PV pada modul PV yang mengalami gangguan shading dapat mempengaruhi secara signifikan seluruh sel yang terkoneksi seri pada modul PV tersebut [12]. Hal ini sesuai dengan penelitian oleh Galeano bahwa satu sel PV yang terkoneksi secara seri merupakan jalur foton yang mempengaruhi seluruh sel pada modul PV di mana sel PV yang mengalami gangguan shading menghasilkan arus photo total teriluminasi $\left(I_{p h T t i}\right)$ yang merupakan akumulasi dari arus photo pada area yang mengalami gangguan shading dan arus photo pada area yang teriluminasi secara sempurna [13]. Sel yang mengalami gangguan shading memiliki area yang tidak menerima sinar matahari dan area yang menerima sinar matahari sehingga menghasilkan arus photo shading $\left(I_{p h s}\right)$ dan arus photo teriluminasi $\left(I_{p h t i}\right)$ seperti pada Gambar 3 sebagai berikut.

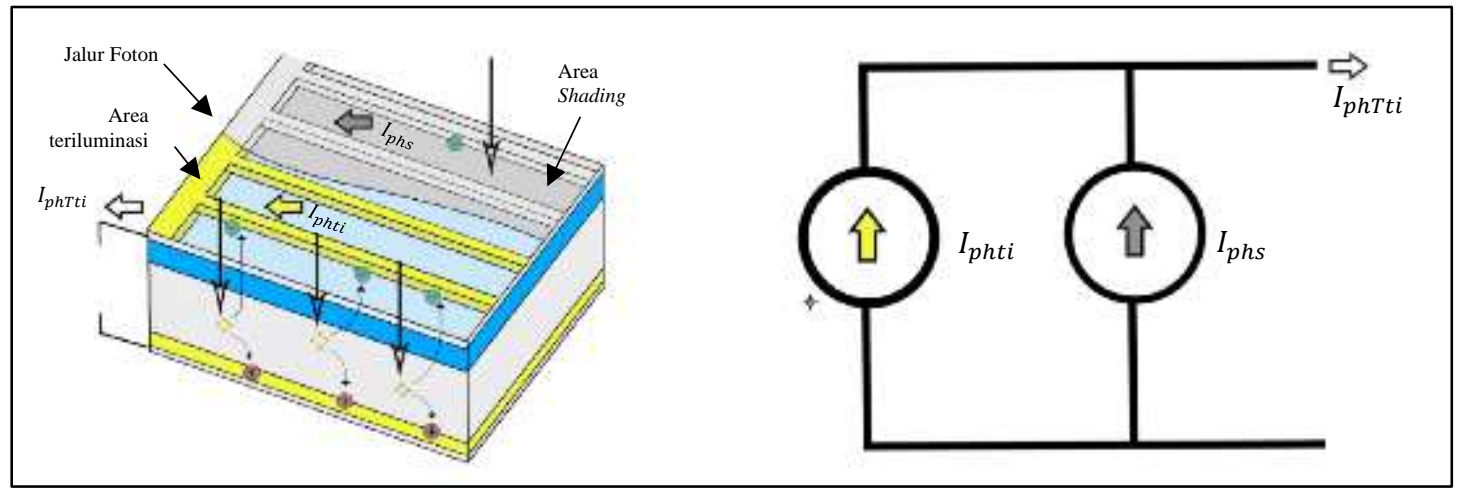

Gambar 3. Jalur Foton pada Sel PV yang Mengalami Shading.

Pada Gambar 3 dapat terlihat bahwa area yang teriluminasi dengan sempurna menghasilkan arus photo teriluminasi $\left(I_{\text {phti }}\right)$ dan pada area yang mengalami gangguan shading menghasilkan arus photo shading, sehingga dari satu sel tersebut yang merupakan jalur foton dari satu grup sel menghasilkan nilai arus photo total yang disebut sebagai arus photo total teriluminasi $\left(I_{p h T t i}\right)$. Penelitian dari Galeano, Bressan, dan Vargas menghasilkan suatu variabel shading berupa nilai konstanta yang dimasukkan ke dalam persamaan modul PV sehingga tercipta persamaan yang memperhitungkan besaran gangguan shading [14]. Gambar 4 adalah contoh bagaimana keadaan dari gangguan shading menutupi sinar matahari pada sel PV dalam modul PV.

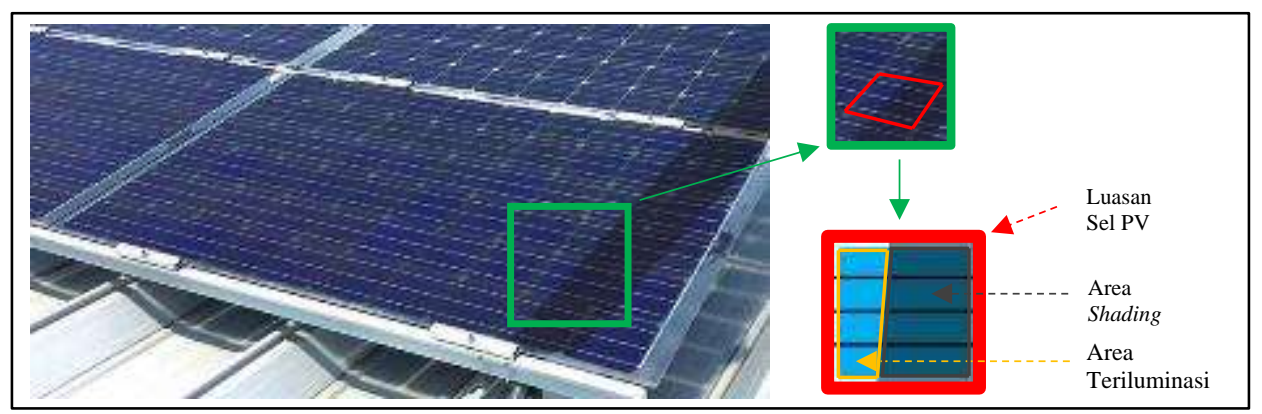

Gambar 4. Modul PV yang Mengalamai Gangguan Shading.

Berdasararkan Gambar 3 dan Gambar 4, ada 2 faktor yang menentukan besaran gangguan shading. Hal yang pertama adalah area sel PV yaitu area yang mengalami shading dan area yang teriluminasi secara sempurna. Hal yang kedua adalah faktor shading $\left(f_{s}\right)$ di mana area yang teriluminasi memiliki tingkat irradiance yang sempurna sedangkan area yang mengalami shading memiliki tingkat irradiance yang bervariasi sesuai dengan shading trasmittance $(\tau)$ objek sumber gangguan shading. Semakin besar nilai faktor shading $\left(f_{s}\right)$ maka besaran irradiance yang terhalang semakin besar. Besaran gangguan shading ditentukan dari rasio shading $(\lambda)$ seperti pada Persamaan 2 sebagai berikut.

$$
\lambda=\left(1-a_{s} f_{s}\right)
$$


Nilai rasio shading $(\lambda)$ pada satu sel PV yang mengalami gangguan shading mempengaruhi keseluruhan sel yang terhubung seri. Hubungan dari sel PV pada grup sel atau modul PV adalah seri. Hal ini mengakibatkan gangguan shading pada satu sel tidak hanya berpengaruh kepada sel tersebut tetapi kepada sel yang lain di mana sel yang mengalami shading memengaruhi jalur foton dari seluruh sel PV yang terhubung seri. Pada modul PV tersebut di mana nilai sebesar 1 menandakan tidak tidak ada gangguan shading yaitu sinar matahari diteruskan sempurna tanpa halangan dan nilai sebesar 0 menandakan gangguan shading secara penuh yaitu sinar matahari dihalangi dengan sempurna. Korelasi antara rasio shading $(\lambda)$ dan persamaan modul PV dapat ditemukan pada Persamaan 3 sebagai berikut

$$
I=\underbrace{I_{p h T t i} \cdot \lambda}_{I_{p h}}-I_{0}\left[\exp \left(\frac{\left(V+I \cdot R_{S}\right) \cdot q}{\mathrm{~A} \cdot N_{S} \cdot k \cdot T_{c}}-1\right)\right]-\frac{V+I \cdot R_{S}}{R_{S h}}
$$

\section{Dioda Bypass dan Grup Sel}

Dioda adalah komponen elektronika daya yang mempunyai karakteristik seperti saklar. Dioda terbuat dari material semikonduktor di mana pada keadaan tertentu bekerja sebagai isolator dan pada keadaan tertentu dapat bekerja juga sebagai konduktor. Dioda memiliki dua keadaan kerja yaitu forward biased yaitu pada saat dioda bekerja mengalirkan arus dan reverse biased pada saat dioda tidak bekerja dan menghalangi arus [15]. Dioda sangat diperlukan sebagai alat proteksi di mana sistem PV merupakan sistem tegangan arus searah dan hasil atau output dari PV adalah daya listrik tegangan arus searah.

Modul PV yang mempunyai grup sel lebih dari satu dimungkinkan untuk adanya pemasangan dioda bypass pada rangkaian tersebut secara paralel dengan grup sel. Grup sel merupakan sel yang terkoneksi secara seri pada satu modul PV di mana grup sel tersebut dipasang paralel dengan dioda bypass seperti pada Gambar 5 sebagai berikut.

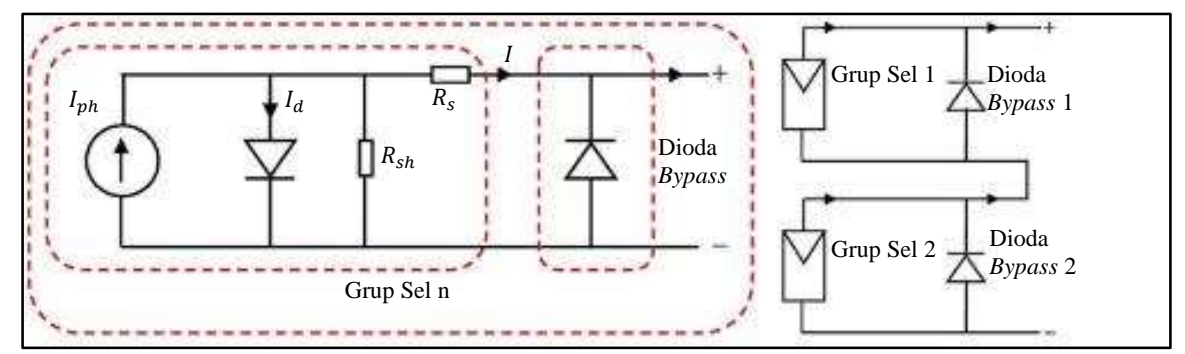

Gambar 5. Grup Sel dan Dioda Bypass.

Pada saat sel PV mengalami gangguan shading dengan keadaan reverse biased, maka dioda bypass akan bekerja meneruskan arus listrik ke group sel yang tidak mengalami gangguan shading [16].

\section{METODOLOGI}

1. Metode Penelitian, Pengujian dan Pengambilan Data.

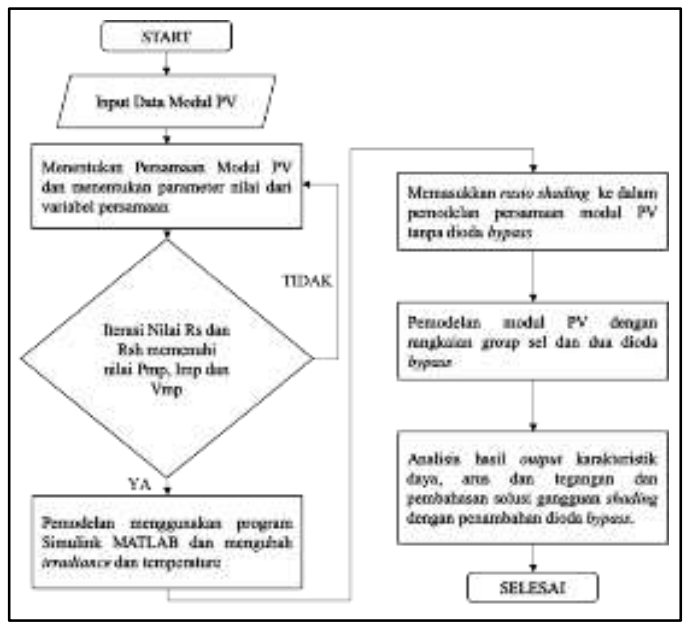

Gambar 6. Diagram Alir Metode Penelitian, Pengujian, dan Pengambilan Data. 


\section{Pemodelan Modul Photovoltaic.}

Pengujian satu modul PV dengan jumlah sel 36 terkoneksi secara seri tanpa menggunakan dioda bypass memiliki rangkaian sesuai pada Gambar 7 sebagai berikut.

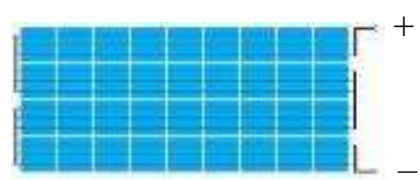

Gambar 7. Rangkaian Modul PV tanpa Dioda Bypass.

Setelah menentukan persamaan dan nilai dari variabel input modul PV, maka selanjutnya dilakukan pemodelan persamaan menggunakan program Simulink MATLAB untuk mendapatkan hasil output berupa karakteristik daya dan arus dan karakteristik arus dan tegangan seperti pada Gambar 8 sebagai berikut.

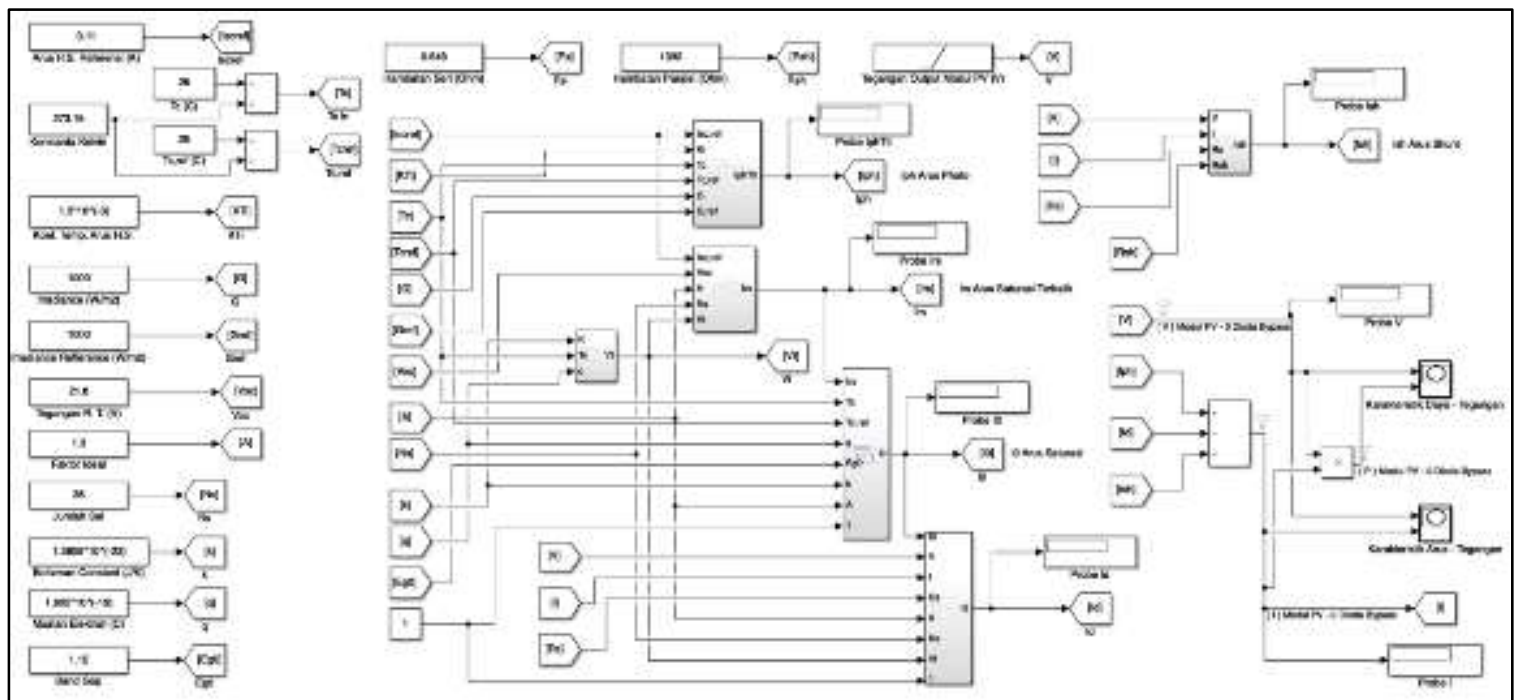

Gambar 8. Pemodelan Persamaan Modul PV.

Pemodelan persamaan modul PV yang tepat harus memenuhi nilai daya maksimum $\left(P_{m p}\right)$ sebesar 49 Watt, nilai arus maksimum $\left(I_{m p}\right)$ sebesar $2.88 \mathrm{~A}$, dan nilai tegangan maksimum $\left(V_{m p}\right)$ sebesar $17 \mathrm{~V}$ sesuai dengan datasheet dari modul PV tersebut. Pemodelan persamaan modul PV dengan nilai hambatan seri sebesar $0.548 \mathrm{Ohm}$ dan nilai hambatan paralel sebesar $1392 \mathrm{Ohm}$ memenuhi nilai $P_{m p}$, $I_{m p}$ dan $V_{m p}$ seperti pada Gambar 9 sebagai berikut.
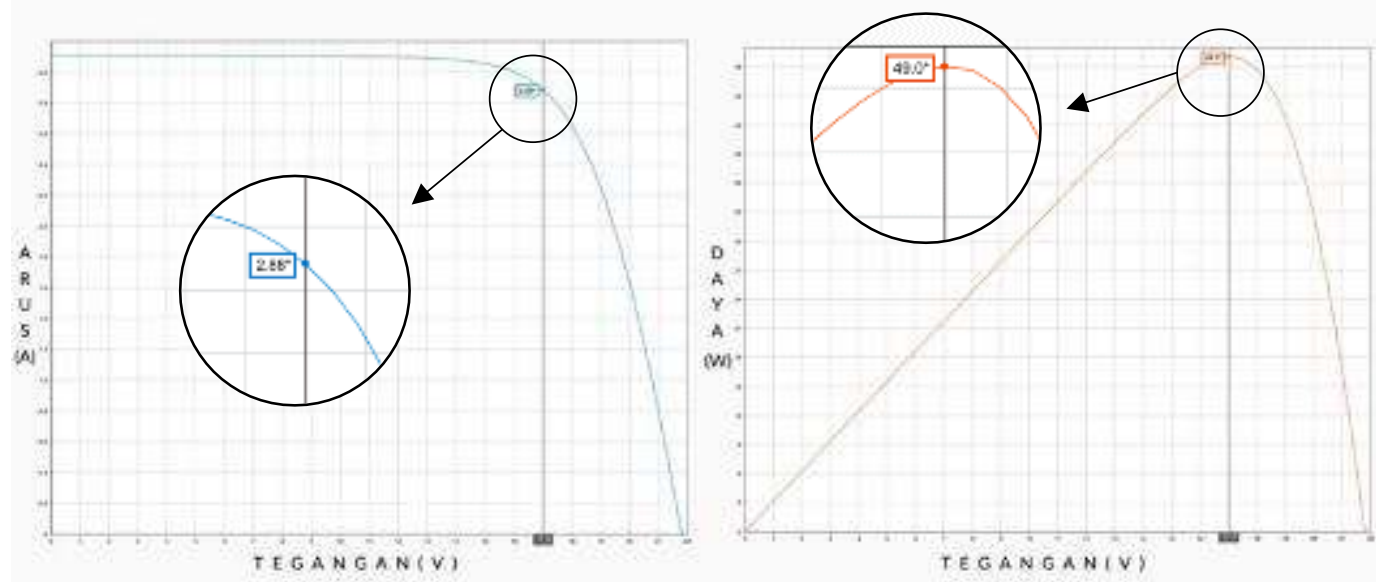

Gambar 9. Karakteristik Daya, Arus dan Tegangan. 
Berdasarkan penelitian dari Patel dan Agarwal, ada dua variabel yang mempengaruhi pembangkitan listrik dari modul PV yaitu irradiance dan temperatur [17]. Pada saat irradiance sebesar $1000 \mathrm{~W} / \mathrm{m}^{2}$ yaitu dalam kondisi uji standar atau standard test condition (STC) dengan temperatur yang berubah - ubah mulai dari $0{ }^{\circ} \mathrm{C}, 25^{\circ} \mathrm{C}, 45^{\circ} \mathrm{C}$, dan $65^{\circ} \mathrm{C}$ menghasilkan karakteristik arus dan tegangan pada Gambar 10a dan karakteristik daya dan tegangan pada Gambar 10b sebagai berikut.

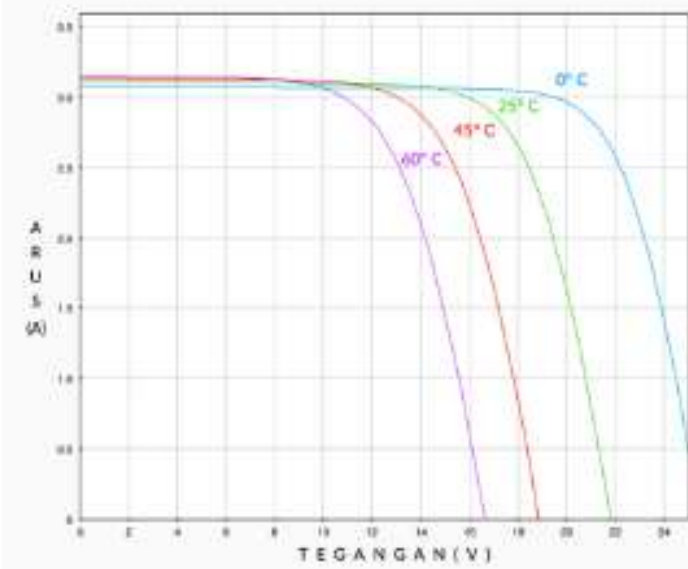

(a)

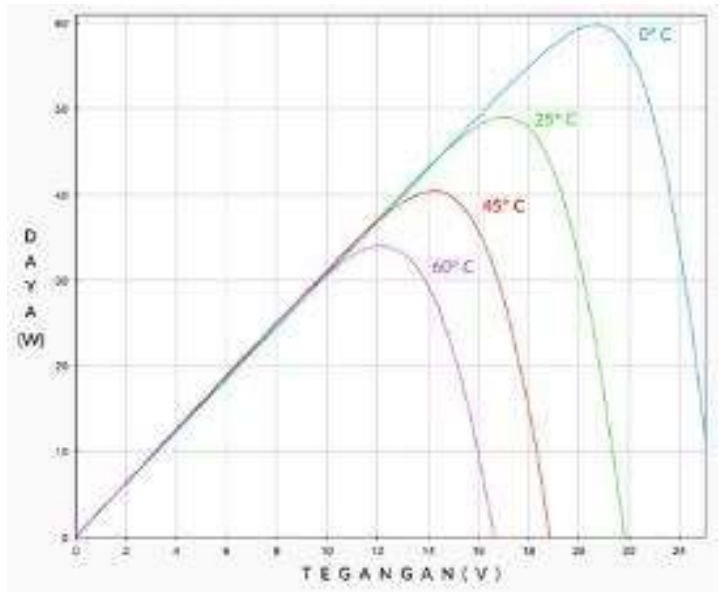

(b)

Gambar 10 a, b. Karakteristik Arus, Daya dan Tegangan pada Temperatur yang Berbeda.

Pengujian modul PV pada saat temperatur kondisi STC sebesar $25^{\circ} \mathrm{C}$ dan dengan irradiance yang berubah - ubah mulai dari $1000 \mathrm{~W} / \mathrm{m}^{2}, 800 \mathrm{~W} / \mathrm{m}^{2}, 600 \mathrm{~W} / \mathrm{m}^{2}, 400 \mathrm{~W} / \mathrm{m} 2$, dan $200 \mathrm{~W} / \mathrm{m}^{2}$ menghasilkan karakteristik arus dan tegangan pada Gambar 11a dan karakteristik daya dan tegangan pada Gambar 11b sebagai berikut.

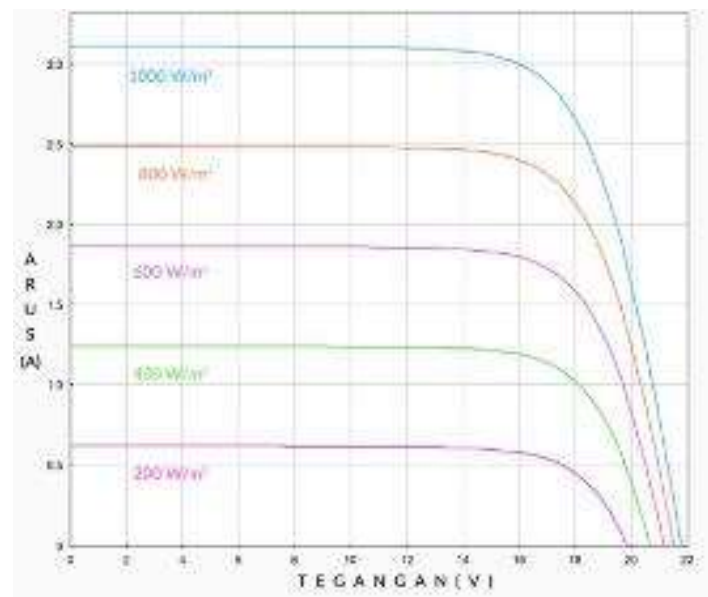

(a)

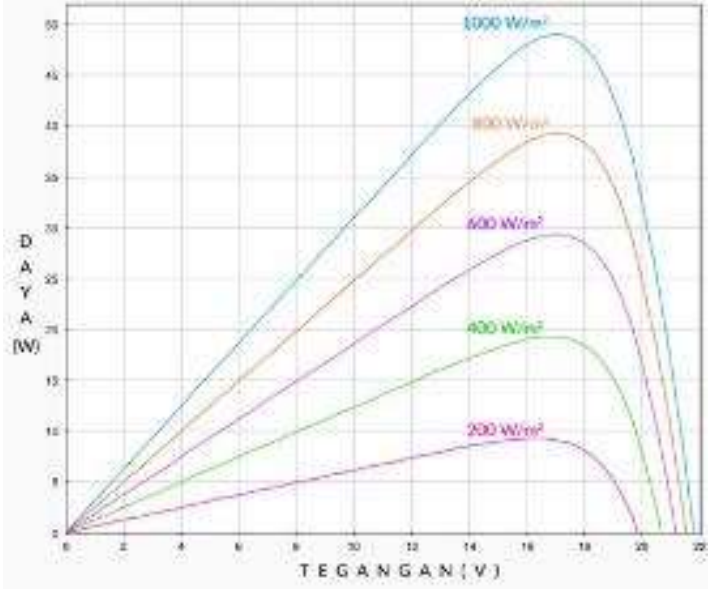

(b)

Gambar 11 a, b. Karakteristik Arus, Daya, dan Tegangan pada Irradiance yang Berbeda.

3. Pemodelan Modul PV tanpa dan dengan Dioda Bypass pada saat Gangguan Shading.

Modul PV yang memiliki dioda bypass dan yang tidak memiliki dioda bypass dengan nilai irradiance pada kondisi STC sebesar $1000 \mathrm{~W} / \mathrm{m}^{2}$, nilai temperatur pada kondisi STC sebesar $25{ }^{\circ} \mathrm{C}$, nilai hambatan seri dan paralel yang disesuaikan agar memenuhi nilai daya, arus, dan tegangan maksimumnya, dan dengan penambahan rasio shading $(\lambda)$ dimodelkan menggunakan program Simulink MATLAB seperti pada Gambar 12,a,b sebagai berikut 


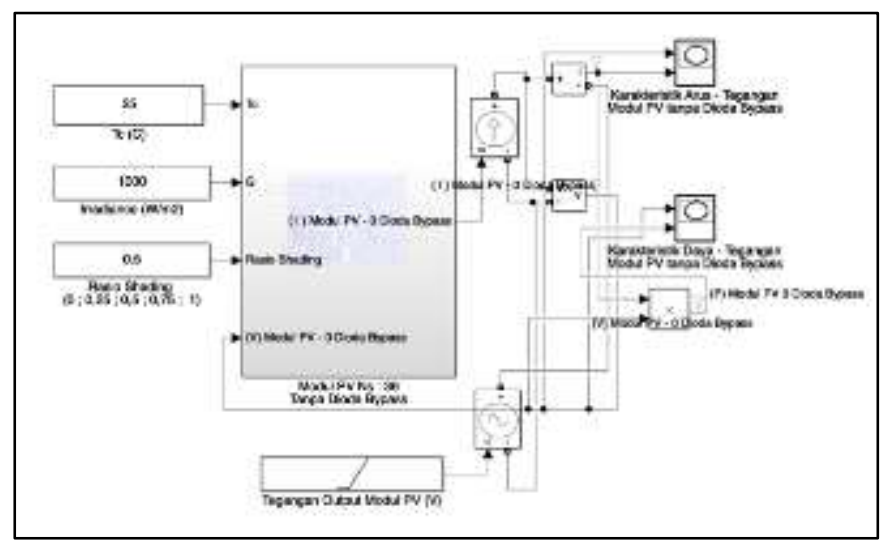

(a)

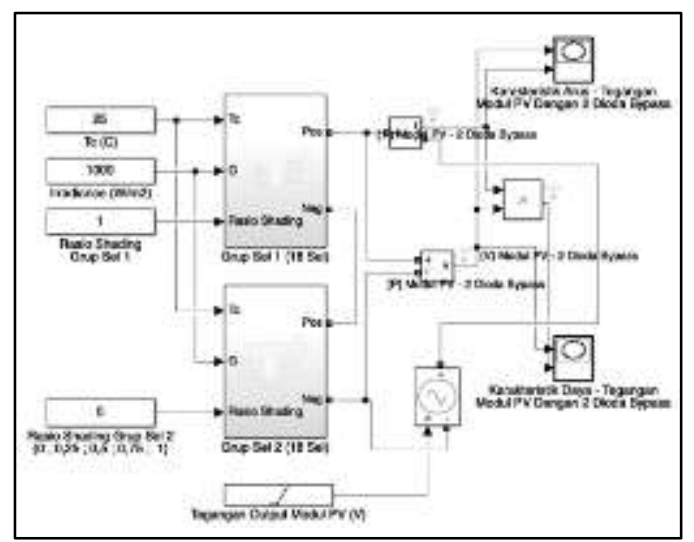

(b)

Gambar 12 a, b. Pemodelan Persamaan Modul PV tanpa dan dengan Dioda Bypass.

Hasil dari pemodelan tersebut adalah karakteristik arus dan tegangan dan karakteristik daya dan tegangan. Besarnya nilai dari gangguan shading ditentukan dari nilai 1 sampai 0 untuk merepresentasikan keadaan saat modul PV terkena iluminasi secara sempurna yaitu saat nilai $\lambda$ sama dengan 1 dan keadaan saat shading secara sempurna yaitu saat nilai $\lambda$ sama dengan 0 . Pengujian gangguan shading yang akan dilakukan adalah salah satu sel dari 36 sel pada modul PV mengalami gangguan shading. Satu sel yang mengalami gangguan shading dapat merepresentasikan seluruh sel yang terdapat pada grup sel dalam modul PV tersebut sehingga satu sel yang mengalami gangguan shading mempengaruhi seluruh sel pada modul PV atau pada grup sel dari modul PV tersebut sementara nilai besaran irradiance dan temperatur dipertahankan pada kondisi STC yaitu sebesar $1000 \mathrm{~W} / \mathrm{m}^{2}$, nilai temperatur pada kondisi STC sebesar $25^{\circ} \mathrm{C}$. Skema gangguan shading dapat digambarkan seperti pada Gambar 13 sebagai berikut.
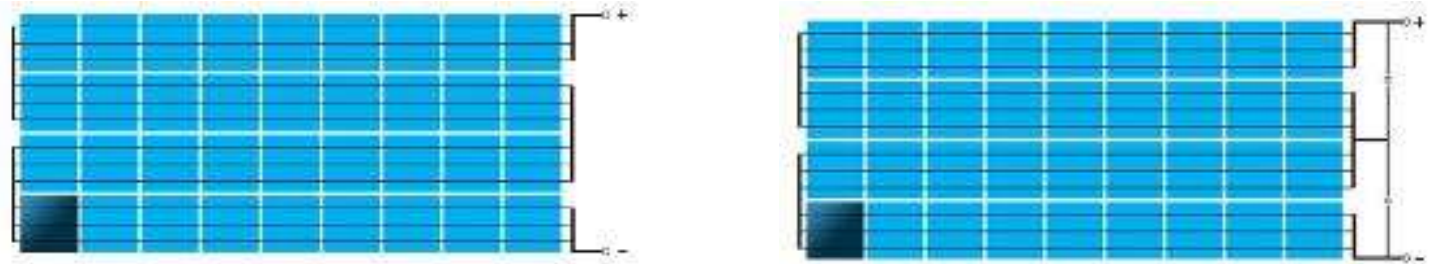

Gambar 13. Skema Shading Modul PV tanpa dan dengan Dioda Bypass.

Besarnya ukuran nilai dari gangguan shading ditentukan dari faktor shading $\left(f_{s}\right)$, shading transmittance $(\tau)$, dan rasio shading $(\lambda)$. Gangguan shading pada modul PV diuji dengan memasukkan rasio shading $(\lambda)$ yang berbeda - beda mulai dari 1, 0.75, 0.5, 0.25 dan 0 untuk menggambarkan output dari modul PV berupa karakteristik arus dan tegangan dan karakteristik daya dan tegangan.

Hasil pengujian yang merupakan karakteristik arus dan tegangan menggambarkan bagaimana gangguan shading mempengaruhi modul PV dengan jumlah sel sebanyak 36 yang terkoneksi secara seri tanpa dioda bypass pada Gambar 14a dan dibandingkan dengan modul PV dengan jumlah sel sebanyak 36 yang memiliki 2 dioda bypass pada 2 grup sel dengan masing - masing 18 sel setiap grupnya pada Gambar 14b sebagai berikut. 


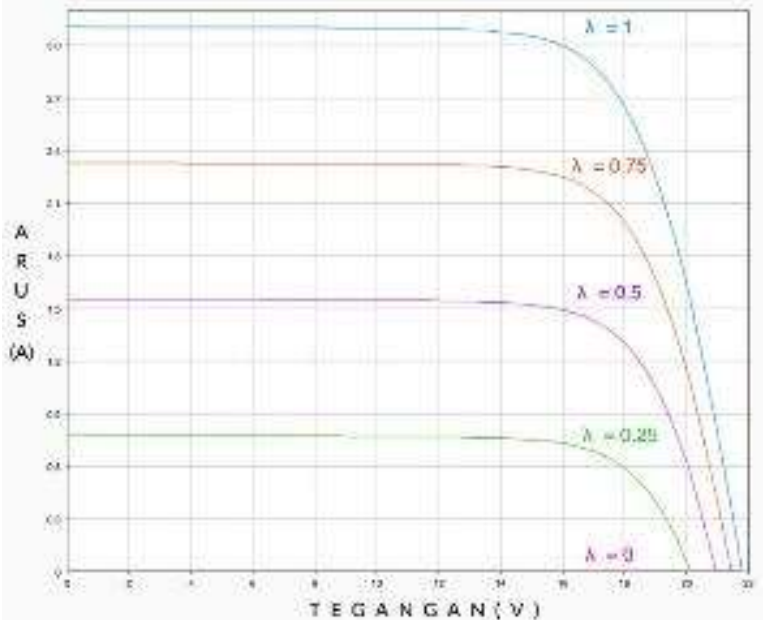

(a)

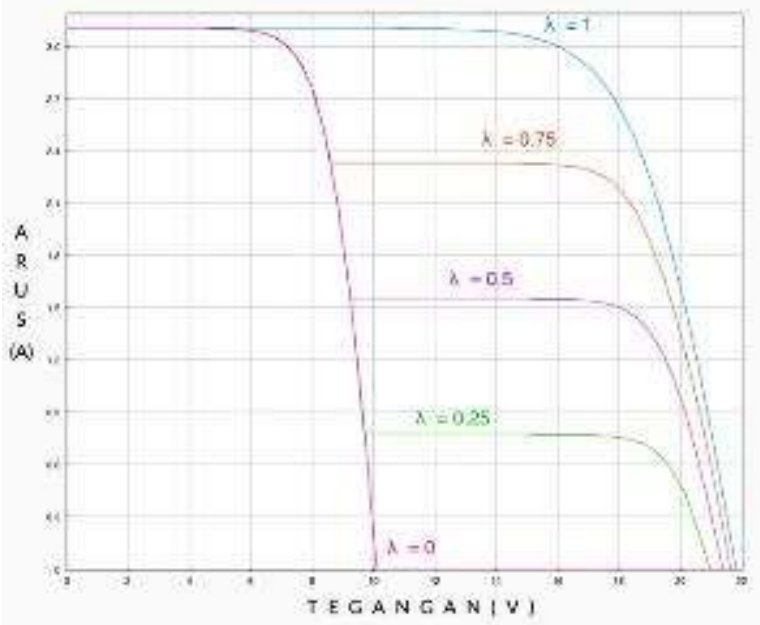

(b)

Gambar 14 a, b. Karakteristik Arus dan Tegangan Modul PV tanpa dan dengan Dioda

Bypass.

Pada saat nilai rasio shading sama dengan 1 di mana objek sebagai sumber gangguan shading tersebut meneruskan seluruh sinar matahari sehingga permukaan sel PV tersebut teriluminasi secara sempurna dan sama sekali tidak mengalami gangguan shading, modul PV yang tidak memiliki dioda bypass dan yang memiliki dioda bypass menghasilkan karakteristik arus dan tegangan yang sama. Namun, pada saat nilai rasio shading berubah dari $0.75,0.5,0.25$, dan 0 yang artinya salah satu sel tersebut mengalami gangguan shading dan besaran tingkat irradiance semakin berkurang pada permukaan sel tersebut sehingga menghasilkan karakteristik arus dan tegangan yang berbeda. Hal ini disebabkan karena modul PV yang memiliki dioda bypass memiliki 2 grup sel sehinga satu sel yang mengalami gangguan shading hanya mempengaruhi satu grup sel atau sebagian dari seluruh sel pada modul PV tersebut.

Hasil pengujian gangguan shading yang merupakan karakteristik daya dan tegangan pada modul PV yang tidak memiliki dioda bypass pada Gambar 15a dibandingkan dengan modul PV yang memiliki dioda bypass dapat dilihat pada Gambar $15 \mathrm{~b}$ sebagai berikut.

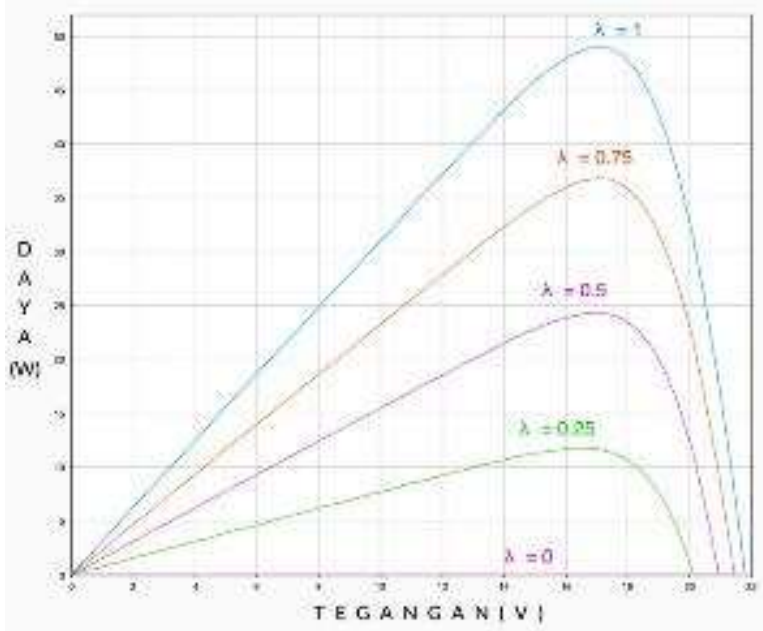

(a)

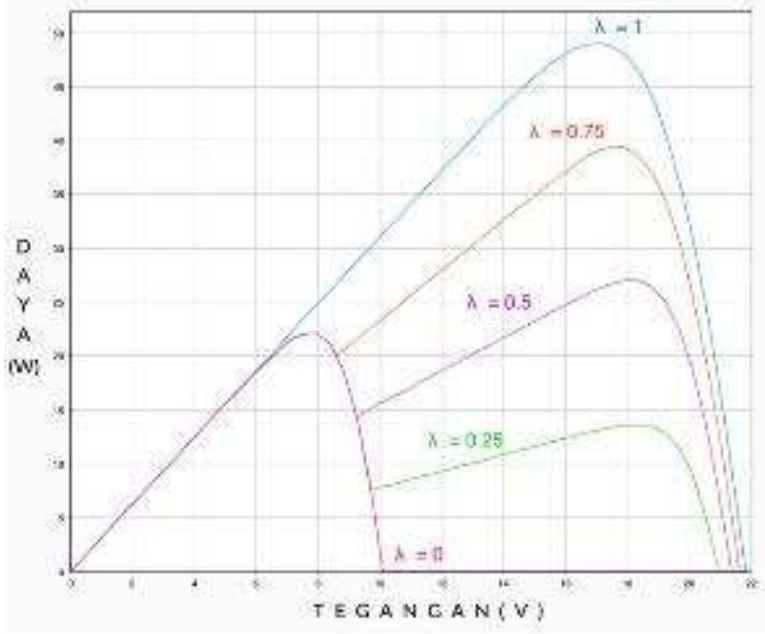

(b)

Gambar 15 a, b. Karakteristik Daya dan Tegangan Modul PV tanpa dan dengan Dioda Bypass.

Pada saat terjadi gangguan shading, berdasarkan Gambar 15a di mana modul PV tanpa dioda bypass menghasilkan daya maksimum yang lebih rendah dibandingkan dengan Gambar $15 \mathrm{~b}$ di mana modul PV yang memiliki dioda bypass. Karakteristik arus dan tegangan dan karakteristik daya dan 
tegangan yang diobservasi titik maksimumnya menghasilkan nilai daya, arus, dan tegangan maksimum yang dapat dilihat pada Tabel 1 sebagai berikut.

Tabel 1. Titik Maksimum Daya, Arus, dan Tegangan Modul PV tanpa Dioda Bypass.

\begin{tabular}{|c|c|c|c|}
\hline Rasio Shading & \multicolumn{3}{|c|}{ Titik Maksimum } \\
\cline { 2 - 4 }$(\lambda)$ & Daya $(\mathrm{W})$ & Arus $(\mathrm{A})$ & Tegangan $(\mathrm{V})$ \\
\hline 1 & 49.0 & 2.88 & 17 \\
\hline 0.75 & 36.8 & 2.16 & 17 \\
\hline 0.5 & 24.3 & 1.43 & 17 \\
\hline 0.25 & 11.7 & 0.69 & 17 \\
\hline 0 & 0 & 0 & 0 \\
\hline
\end{tabular}

Pada Tabel 1 yang merupakan hasil pemodelan persamaan modul PV tanpa dioda bypass dengan nilai $\lambda$ bervariasi mulai dari 1 sampai 0 , Daya maksimum dan arus maksimum mengalami penurunan yang signifikan seiring dengan bertambahnya besaran gangguan shading pada modul PV tersebut. Namun nilai dari tegangan maksimumnya menunjukkan nilai yang tetap sebesar $17 \mathrm{~V}$ pada setiap besaran gangguan shading. Pada saat nilai $\lambda$ sama dengan 1 menandakan modul PV tersebut tidak mengalami gangguan shading.

Modul PV yang memiliki 2 grup sel dengan 2 dioda bypass menghasilkan karakteristik daya dan tegangan dengan 2 titik puncak pada saat mengalami gangguan shading [18], yaitu ketika nilai rasio shadingnya $(\lambda)$ lebih kecil dari satu. Hal ini disebabkan karena dioda bypass yang bekerja dan grup sel yang terpisah mengakibatkan sel yang mengalami gangguan shading tidak mempengaruhi seluruh sel yang ada pada modul PV tersebut. Hasilnya, modul PV yang memiliki 2 grup sel dan 2 dioda bypass menghasilkan 2 titik puncak yaitu untuk nilai daya maksimum, nilai arus maksimum dan nilai tegangan maksimum. Pemodelan pada program simulink MATLAB menjadikan grup sel dan menambahkan dioda bypass sesuai seperti pada Gambar 12b yang menghasilkan karakteristik arus dan tegangan dan daya dan tegangan yang dapat dilihat pada Gambar 14b dan Gambar 15b, dan besaran nilai yang merupakan hasil dari 2 titik puncak pada modul PV dengan 2 dioda bypass yang mengalami gangguan shading dapat dilihat pada Tabel 2 sebagai berikut.

Tabel 2. Titik Puncak 1 dan 2 Daya, Arus dan Tegangan Modul PV dengan Dioda Bypass.

\begin{tabular}{|c|c|c|c|c|c|c|}
\hline \multirow{2}{*}{$\begin{array}{c}\text { Rasio } \\
\text { Shading }(\lambda)\end{array}$} & \multicolumn{3}{|c|}{ Titik Puncak 1 } & \multicolumn{3}{c|}{ Titik Puncak 2 } \\
\cline { 2 - 7 } & Daya $(\mathrm{W})$ & Arus (A) & Tegangan $(\mathrm{V})$ & Daya $(\mathrm{W})$ & Arus (A) & Tegangan $(\mathrm{V})$ \\
\hline 1 & 49.0 & 2.88 & 17 & - & - & - \\
\hline 0.75 & 22.1 & 2.78 & 8 & 39.5 & 2.25 & 17.5 \\
\hline 0.5 & 22.1 & 2.78 & 8 & 27.1 & 1.50 & 18.0 \\
\hline 0.25 & 22.1 & 2.78 & 8 & 13.7 & 0.74 & 18.4 \\
\hline 0 & 22.1 & 2.78 & 8 & 0 & 0 & 0 \\
\hline
\end{tabular}

Tabel 2 merupakan hasil pemodelan persamaan modul PV yang memiliki 2 dioda bypass, Pada saat nilai $\lambda$ sama dengan 1 yang menandakan modul PV tersebut tidak mengalami gangguan shading sehingga menghasilkan besasran nilai daya, arus, dan tegangan maksimum sesuai dengan modul PV yang tidak memiliki dioda bypass yang tercantum pada Tabel 1 dan hanya memiliki satu nilai puncak dengan $P_{m p}$ sebesar 49 Watt, $I_{m p}$ sebesar $2.88 \mathrm{~A}$, dan $V_{m p}$ sebesar $17 \mathrm{~V}$. Namun, saat nilai $\lambda$ berubah lebih kecil dari satu atau pada saat gangguan shading terjadi, modul PV tersebut menghasilkan 2 titik puncak untuk daya, arus, dan tegangannya. Pada saat nilai $\lambda$ sebesar 0.75 dan 0.5 , nilai daya, arus, dan tegangan pada titik puncak 2 lebih besar dibandingkan dengan nilai titik puncak 1 . Namun, pada saat nilai $\lambda$ sebesar 0.25 dan 0 , nilai daya, arus, dan tegangan pada titik puncak 1 lebih besar dibandingkan dengan nilai titik puncak 2 . Pada saat nilai $\lambda$ berada di antara 1 dan 0 terdapat 2 titik puncak daya, arus, dan tegangan. Jika membandingkan dengan Tabel 1 dapat terlihat bahwa nilai maksimum daya dan arus dibandingkan dengan Tabel 2 yaitu modul PV yang memiliki 2 dioda bypass menghasilkan nilai maksimum yang lebih besar namun untuk tegangan pada saat nilai $\lambda$ sebesar 0.25 dan 0 , untuk daya yang lebih besar dan nilai arus yang lebih besar memiliki nilai tegangan yang lebih kecil hal tersebut diakibatkan karena jumlah total sel yang bekerja hanya sebagian sehingga tegangannya pun berkurang 
sebagian. Pada saat keadaan gangguan shading sempurna yaitu ketika nilai rasio shading $(\lambda)$ sebesar 0 nilai daya maksimum dari modul PV yang tidak memiliki dioda bypass sebesar $0 \mathrm{~W}$ dan untuk modul PV yang memiliki 2 dioda bypass menghasilkan daya maksimum sebesar $22.1 \mathrm{~W}$. Terdapat kenaikan efisiensi daya sebesar $45 \%$ dibandingkan dengan modul PV yang tidak memiliki diode bypass.

\section{KESIMPULAN}

Berdasarkan hasil pengujian dan data yang diperoleh dapat disimpulkan hal-hal sebagai berikut :

1. Pemodelan dengan persamaan modul PV yang detail dengan nilai - nilai variabel yang akurat berhasil memenuhi nilai maksimum daya $\left(P_{m p}\right)$ sebesar 49 Watt, nilai maksimum arus $\left(I_{m p}\right)$ sebesar $2.88 \mathrm{~A}$, dan nilai maksimum tegangan $\left(V_{m p}\right)$ sebesar $17 \mathrm{~V}$.

2. Perubahan irradiance dan temperatur mempengaruhi karakteristik daya, arus dan tegangan sesuai dengan hasil dari pengujian pemodelan persamaan modul PV tersebut.

3. Pada saat terjadi gangguan shading, modul PV yang memiliki 2 grup sel dengan 2 dioda bypass menghasilkan karakteristik daya, arus, dan tegangan dengan 2 titik puncak dibandingkan dengan modul PV yang tidak memiliki dioda bypass yang hanya memiliki satu titik puncak yaitu nilai maksimumnya.

4. Jika membandingkan hasil dari Tabel 1 dan Tabel 2 nilai puncak daya atau nilai maksimum daya dari modul PV yang memiliki dioda bypass lebih besar dibandingkan dengan nilai maksimum daya dari modul PV yang tidak memiliki dioda bypass pada saat gangguan shading terjadi yaitu pada saat rasio shading $(\lambda)$ sebesar $0.75,0.5,0.25$, dan 0 , maka dapat disimpulkan bahwa dioda bypass meningkatkan nilai maksimum daya dari modul PV yang salah satu selnya mengalami shading.

5. Pada saat nilai rasio shading $(\lambda)$ sama dengan 0 yaitu pada salah satu selnya mengalami gangguan shading yang sempurna, modul PV yang tidak memiliki dioda bypass menghasilkan daya sebesar $0 \mathrm{~W}$, sementara untuk modul PV yang memiliki 2 dioda bypass menghasilkan daya sebesar $22.1 \mathrm{~W}$ atau mengalami kenaikan sebesar 45 dalam pembangkitan dayanya.

6. Berdasarkan hasil pengujian yaitu Gambar 14b, 15b, dan Tabel 2, nilai maksimumnya dapat kita tentukan melalui hasil pemodelan. Namun, dalam kondisi nyata diperlukan Maximum Power Point Tracker (MPPT) yang merupakan perangkat elektronika daya yang dapat menentukan titik puncak terbesar. Hal tersebut dapat menjadi pembahasan dan penelitian yang lebih lanjut.

\section{DAFTAR PUSTAKA}

[1] Muhammad H Rashid, Power electronics: circuits, devices, and applications Fourth Edition. Harlow: Pearson, 2014.

[2] I. Md. Rabiul, K. R. Naruttam, and R. Saifur, Renewable energy and energy sources. 2018.

[3] R. Ehrlich and H. A. Geller, Renewable energy, second edition: A First Course. 2017.

[4] T. Afrin Chandel, M. A. Mallick, and M. Y. Yasin, "Performance of partially shaded solar photovoltaic system," Int. J. Recent Technol. Eng., vol. 7, no. 6, pp. 1444-1449, 2019.

[5] W. Opare, C. Kang, Y. Gu, and N. Mao, "Combination effects of roof coating and solar photovoltaic system in the tropical region of Ghana: A case study," Energy Explor. Exploit., vol. 37, no. 5, pp. 1455-1476, 2019, doi: 10.1177/0144598718803228.

[6] R. V. F. Batista, "The impact of shadowing in photovoltaic systems and how to minimizing it," 2018.

[7] G. Conibeer and A. Willoughby, Solar Cell Materials: Developing Technologies. John Wiley \& Sons, Ltd, 2014.

[8] M. Gul, Y. Kotak, and T. Muneer, Review on recent trend of solar photovoltaic technology, vol. 34, no. 4. 2016.

[9] K. Abdulmawjood, S. S. Refaat, and W. G. Morsi, "Detection and prediction of faults in photovoltaic arrays: A review," Proc. - 2018 IEEE 12th Int. Conf. Compat. Power Electron. Power Eng. CPE-POWERENG 2018, pp. 1-8, 2018, doi: 10.1109/CPE.2018.8372609.

[10] MESSAOUDA AZZOUZI \& MILAN STORK, "Modeling and Simulation of a Photovoltaic Cell Considering Single-Diode Model," MPACT Int. J. Res. Eng. Technol. (IMPACT IJRET), vol. 2, no. 11, pp. 19-28, 2014.

[11] V. Lo Brano, A. Orioli, G. Ciulla, and A. Di Gangi, "An improved five-parameter model for 
photovoltaic modules," Sol. Energy Mater. Sol. Cells, vol. 94, no. 8, pp. 1358-1370, 2010, doi: 10.1016/j.solmat.2010.04.003.

[12] E. E. Ekpenyong and F. . Anyasi, "Effect of Shading on Photovoltaic Cell," IOSR J. Electr. Electron. Eng., vol. 8, no. 2, pp. 01-06, 2013, doi: 10.9790/1676-0820106.

[13] A. G. Galeano and C. Roche, "Study of Photovoltaic System Integration in Microgrids through Modeling and Supervision of its Components Using HiLeS," 2019.

[14] A. G. Galeano, M. Bressan, F. J. Vargas, and C. Alonso, "Shading ratio impact on photovoltaic modules and correlation with shading patterns," Energies, vol. 11, no. 4, pp. 1-26, 2018, doi: 10.3390/en1 1040852.

[15] L. L. Boylestad, Robert; Nashelsky, Electronic devices and Circuit Theory. Prentice Hall, 2013.

[16] S. Sara, "Analysis and simulation of shading effects on photovoltaic cells," University of Gävle, 2016.

[17] H. Patel and V. Agarwal, "MATLAB-based modeling to study the effects of partial shading on PV array characteristics," IEEE Trans. Energy Convers., vol. 23, no. 1, pp. 302-310, 2008, doi: 10.1109/TEC.2007.914308.

[18] J. Gosumbonggot and G. Fujita, "Partial shading detection and global maximum power point tracking algorithm for photovoltaic with the variation of irradiation and temperature," Energies, vol. 12, no. 2, 2019, doi: 10.3390/en12020202. 